\title{
HUBUNGAN SER VICE RECOVERY DENGAN LOYALITAS NASABAH PADA BANK BENGKULU UNIT PANORAMA
}

\author{
Siti Hanila ${ }^{1)}$ - Meimon Putra Abela ${ }^{2)}$ \\ Universitas Dehasen Bengkulu \\ st.hanila@gmail.com \\ meimonpabela@gmail.com
}

\begin{abstract}
Service recovery is a significant determinant of customer satisfaction and loyalty. The effort to maintain a relational relationship with dissatisfied customers through effective service recovery has become the main focus of customer retention strategies. The purpose of this study is to find out the relationship between service recovery and customer loyalty at the Bengkulu Unit Panorama Bank. The samples in this study were 80 customers who received services from the Bank Bengkulu Panorama Unit and the sampling technique was accidental sampling technique. The data collection method used quesionary and the analyst method used was Spearman rank correlation and data truth testing with t test
\end{abstract}

Keywords: Service Recovery, Loyalty

\section{PENDAHULUAN}

Setiap organisasi jasa berusaha supaya tidak terjadi service failure dengan tujuan untuk menghemat cost yang harus dikeluarkan untuk memperbaiki service failure tersebut. Layanan yang bebas dari kesalahan (failure-free service) lebih diinginkan daripada perbaikan yang sempurna (excellent recovery). Namun berbagai situasi dan kondisi menyebabkan setiap elemen organisasi tidak bisa mengelak dari terjadinya service failure. Dengan demikian organisasi harus melakukan recovery supaya dapat mempertahankan pelanggan.

Persaingan yang ketat antar perusahaan dewasa ini mendorong setiap perusahaan untuk memberikan layanan terbaik kepada pelanggan. Masing-masing perusahaan mempunyai program yang terus diperbarui. Program tersebut dapat berbentuk layanan-layanan baru yang semakin memudahkan pelanggan, ada pula yang menawarkan program undian berhadiah. Semua itu dimaksudkan untuk sebanyak mungkin menarik masyarakat untuk menjadi pelanggan baru, juga untuk mempertahankan supaya pelanggan lama tidak beralih ke perusahaan lain. Salah satu usaha yang dilakukan perusahaan supaya mempunyai daya saing yang tinggi adalah dengan mengadopsi setiap perkembangan teknologi, khususnya informasi dan komunikasi.

Pemulihan layanan (service recovery) merupakan salah satu determinan signifikan kepuasan dan loyalitas pelanggan. Usaha mempertahankan hubungan relasional dengan pelanggan yang tidak puas melalui pemulihan layanan yang efektif telah menjadi fokus utama strategi retensi pelanggan. Pada hakikatnya, pemulihan layanan merupakan tindakan yang dilakukan penyedia jasa untukmenyelesaikan keluhan yang terjadi akibat kegagalan memberikan layanan danuntuk mempertahankan customer's goodwill (Lovelock, 2016:77). Program pemulihan layanan formal, perusahaan menambah manfaat-manfaat pokok kepada produk dan jasa yang ditawarkan, sekaligus meningkatkan komponen layanan dalam rantai nilai perusahaan.

Griffin (2015:11) mengungkapkan bahwa tingginya loyalitas pelanggan sesuai dengan perilaku pembelian yang biasa diperlihatkan oleh pelanggan yang loyal. Perilaku pembelian dalam diri seorang pelanggan yang loyal menunjukkan kesamaan pada empat sifat, yaitu pembelian secara berulang, pembelian produk dari perusahaan yang sama, anjuran kepada orang 
lain untuk menggunakan produk yang sama, serta kecendrungan mengabaikan produk kompetitor.

Sementara Kotler (2014:18) berpendapat bahwa upaya pencapaian kesetiaan pelanggan merupakan tujuan pemasaran pada milenium mendatang sehingga perusahaan dituntut untuk mampu memupuk keunggulan bersaingnya, melalui upaya yang kreatif, inovatif serta efisien, sehingga menjadi pilihan dari banyak pelanggan yang pada diharapkan loyal nantinya.

Lebih lanjut dikemukakan bahwa loyalitas memiliki hubungan dengan dua kondisi penting, yaitu retensi pelanggan (customer retention) dan total pangsa pasar (total share of customer). Retensi pelanggan menjelaskan lamanya hubungan dengan pelanggan. Tingkat retensi pelanggan adalah presentase pelanggan yang telah memenuhi sejumlah pembelian ulang selama periode waktu yang terbatas. Pangsa pelanggan suatu perusahaan menunjukkan presentase dari anggaran pelanggan yang dibelanjakan ke perusahaan tersebut.

Bank Bengkulu unit Panorama merupakan unit dari Bank Bengkulu yang berlokasi di Panorama sehingga dinamakan Bank Bengkulu Unit Panorama. Bagi bank Bengkulu unit Panorama, nasabah merupakan harta yang sangat berharga dan harus dipertahankan untuk itu bank Bengkulu unit Panorama harus memperhatikan hal-hal yang bisa membuat nasabah menjadi setia atau loyal sehingga nasabah tetap memilih bank Bengkulu unit Panorama untuk melakukan transasksi perbankan.Fenomena yang ada di Bank Bengkulu unit Panorama pada saat ini adalah bahwa masih kurangnnya pelayanan para service recovery karena pada saat terjadi suatu masalah yang dialami oleh nasabah terkadang bagian customer service tidak lansung memberikan solusi dengan tepat dan terjadinya perbaikan pelayanan yang berbelit-belit. Berdasarkan latar belakang di atas, maka penulis tertarik untuk mengambil judul penelitian yaitu "Hubungan Service Recovery dengan Loyalitas Nasabah pada Bank Bengkulu unit Panorama”.

\section{LANDASAN TEORI}

Penelitian oleh Nursyamsiah (2012) dengan judul Hubungan Service Recovery terhadap Loyalitas. Pengujian hubungan dimensi Service Recovery yang terdiri darikeadilan distributif, keadilan procedural dan keadilan interaksional secarapartial maupun simultan menunjukkan hubungan yang signifkan terhadap kepuasan pelanggan. Hal ini berarti bahwa tingkat pemulihan kegagalan pelayanan yang semakin tinggi maka tingkat kepuasan pelanggan juga akan semakin tinggi pula, begitu juga sebaliknya apabila tingkat pemulihan kegagalan pelayanan rendah maka tingkat kepuasan pelanggan juga akan semakin rendah.

Penelitian yang dilakukan oleh Kaunang (2015) dengan judul Analisis Hubungan Kualitas Produk dan Kualitas Layanan terhadap Loyalitas Nasabah yang dimediasi oleh Kepuasan Nasabah (Studi pada Nasabah Taplus PT Bank Negara Indonesia (Persero) Tbk Kantor Cabang Manado). Hasil penelitian menunjukkan : terdapat hubungan yang positif signifikan atas kualitas produk terhadap kepuasan nasabah Taplus BNI KCU Manado tetapi tidak terdapat hubungan yang positif signifikan atas kualitas layanan terhadap kepuasan nasabah Taplus BNI KCU Manado. Selanjutnya, kepuasan nasabah berhubungan positif dan signifikan terhadap loyalitas nasabah Taplus BNI KCU Manado.

Penelitian yang dilakukan oleh Rashid (2014) dengan judul Does Service Recovery Affect Customer Satisfaction? A Study onCo-Created Retail Industry. Tujuan dari penelitian ini adalah untuk mengetahui hubungan antara pemulihan layanan dan kepuasan pelanggan dalam industri ritel. Industri ritel yang diciptakan bersama yang mencerminkan keterlibatan pelanggan dalam penciptaan nilai bisnis adalah pendekatan yang saling menguntungkan bagi pelanggan dan pengecer khususnya dalam konteks service recovery. Meskipun perhatian utama pada pemulihan layanan telah dinilai dalam konteks perhotelan terutama dalam pengaturan hotel dan restoran, ada eksplorasi yang sangat terbatas dalam konteks ritel yang diciptakan bersama untuk memberikan pemahaman yang cukup untuk ritelmanajemen pemulihan. Kerangka kerja konseptual dan tiga preposisi dikembangkan yang menunjukkan bahwa kepuasan pelanggan dihubungan oleh tiga dimensi keadilan dari pemulihan layanan outcome justice, procedural justice dan interactional 
justice. Implikasi manajerial dari penelitian ini dibahas untuk menunjukkan pentingnya pemulihan layanan dalam memenangkan kembali loyalitas pelanggan.

\section{Bank}

Menurut Kasmir (2016: 24) bank dikenal sebagai lembaga keuangan yang kegiatan utamanya menerima simpanan giro, tabungan dan deposito, bank juga dikenal sebagai tempat untuk meminjam uang. Kemudian pengertian bank menurut Undang-Undang Nomor 10 tahun 1998 bank merupakan badan usaha yang menghimpun dana dari masyarakat dalam bentuk simpanan dan menyalurkannya ke masyarakat dalam bentuk kredit atau bentuk-bentuk lainnya dalam rangka meningkatkan taraf hidup rakyat banyak.

Menurut Martono (2014: 20) bank merupakan salah satu badan usaha lembaga yang bertujuan memberikan pembiayaan, baik dengan alat pembayaran sendiri, dengan uang yang diperolehnya dari orang lain dengan jalan mengedarkan alat-alat pembayaran baru berupa uang giral. Sedangkan pengertian bank menurut Undang-Undang nomor 7 tahun 1992 tentang perbankan bank adalah badan usaha yang menghimpun dana dari masyarakat dalam bentuk simpanan dan menyalurkannya kepada masyarakat dalam rangka meningkatkan taraf hidup rakyat banyak.

Dari pengertian diatas dapat simpulkan bahwa yang dimaksud dengan bank adalah lembaga keuangan atau badan usaha yang bergerak dalam bidang keuangan yang memiliki 3 (tiga) kegiatan utama yaitu: menghimpu dana, menyalurkan dana, dan memberikan jasa kepada bank lainnya dalam rangka meningkatkan taraf hidup rakyat banyak. Bank merupakan salah satu bentuk lembaga keuangan yang memegang peranan penting dalam membangun ekonomi. Bank bukan hanya sebagai lembaga menghimpun dana, menyediakan dana dalam masyarakat, akan tetapi bank juga merupakan suatu lembaga yang memberikan motivasi dan mendorong terciptanya berbagai kegiatan ekonomi.

\section{Manajemen Pemasaran}

Pemasaran mencakup usaha perusahaan yang dimulai dengan mengidentifikasi kebutuhan konsumen yang perlu dipuaskan, menentukan produk yang hendak diproduksi, menentukan harga produk yang sesuai, menentukan cara-cara promosi dan distribusi produk tersebut. Jadi kegiatan pemasaran adalah kegiatan-kegiatan yang saling berhubungan sebagai suatu sistem.

Konsep-konsep inti pemasaran meliputi: kebutuhan, keinginan, permintaan, produksi, utilitas, nilai dan kepuasan; pertukaran, transaksi dan hubungan pasar, pemasaran dan pasar. Kita dapat membedakan antara kebutuhan, keinginan dan permintaan. Kebutuhan adalah suatu keadaan dirasakannya ketiadaan kepuasan dasar tertentu. Keinginan adalah kehendak yang kuat akan pemuas yang spesifik terhadap kebutuhan-kebutuhan yang lebih mendalam. Sedangkan permintaan adalah keinginan akan produk yang spesifik yang didukung dengan kemampuan dan kesediaan untuk membeli produk tersebut.

Manajemen pemasaran berasal dari dua kata yaitu manajemen dan pemasaran. Menurut Kotler dan Armstrong (2014:42) pemasaran adalah analisis, perencanaan, implementasi, dan pengendalian dari program-program yang dirancang untuk menciptakan, membangun, dan memelihara pertukaran yang menguntungkan dengan pembeli sasaran untuk mencapai tujuan perusahaan. Sedangakan manajemen adalah proses perencanaan (planning), pengorganisasian (organizing) penggerakan (actuating) dan pengawasan.

Jadi dapat diartikan bahwa Manajemen Pemasaran adalah sebagai analisis, perencanaan, penerapan, dan pengendalian program yang dirancang untuk menciptakan, membangun, dan mempertahankan pertukaran yang menguntungkan dengan pasar sasaran dengan maksud untuk mencapai tujuan - tujuan organisasi, dari uraian diatas dapat disimpulkan bahwa manajemen pemasaran adalah sebagai kegiatan yang direncanakan, dan diorganisasiknan yang meliputi pendistribusian barang, penetapan harga dan dilakukan pengawasan terhadap kebijakan-kebijakan 
yang telah dibuat yang tujuannya untuk mendapatkan tempat dipasar agar tujuan utama dari pemasaran dapat tercapai.

Proses pemasaran perlu dilakukan oleh setiap perusahaan, karena dengan pemasaran akan menambah kegunaan produk yang ada yaitu kegunaan tempat, waktu dan pemikiran, dan kegiatan pemasaran. Kegiatan pemasaran tersebut didalamnya mempunyai fungsi pemasaran (Swastha, 2016: 196), antara lain:

a. Fungsi pertukaran

Fungsi pertukaran meliputi pembelian dan penjualan. Fungsi ini berkaitan dengan pertukaran barang dari penjual ke pembeli. Fungsi pembelian dilakukan oleh pembeli untuk memilih jenis barang yang akan dibeli, kualitas yang diinginkan, kualitas yang memadai dan penyediaan uang sesuai. Fungsi penjualan paling luas meliputi kegiatan untuk mencapai pasar dan menghubungkan permintaan.

b. Fungsi penyedia fisik

Fungsi penyedia fisik meliputi pengangkutan dan penyimpanan. Fungsi pengangkutan dan penyimpanan berkaitan dengan pemindahan barang-barang dari termpat produksi ke konsumen. Selain itu fungsi tersebut berkaitan pula dengan penyimpanan barang-barang sampai barang tersebut diperlukan oleh konsumen. Fungsi pengangkutan dapat dilakukan dengan kereta api, truk, kapal laut, dan pesawat udara, sedangkan fungsi penyimpanan dapat dilakukan di bagian produksi itu sendiri sampai di gudang umum.

c. Fungsi penunjang.

Fungsi penunjang meliputi pembelian, penanggungan resiko, strandarsasi barang-barang dan grading serta pengumpulan informasi pasar. Fungsi ini dapat membantu pelaksanaan dari fungsi-fungsi lainnya. Fungsi pembelian bertujuan untuk menyediakan dana, melayani penjualan kredit atau menanggung kerugian perusahaan, yang semuanya merupakan kegiatan yang selalu ada di dalam semua kegiatan bisnis. Standarisasi merupakan fungsi yang bertujuan menyederhanakan keperluan-keperluan pembeli dengan menciptakan golongan-golongan barang tertentu yang berdasarkan pada kriteria-kriteria seperti ukuran berat, warna, dan rasa. Grading mengidentifikasikan golongan barang tersebut ke dalam berbagai tingkat kualitas. Fungsi terakhir adalah fungsi penunjang yaitu pengumpulan informasi pasar, bertujuan mengumpulkan berbagai macam informasi yang dapat dipakai oleh menejer pemasaran untuk mengambil keputusan.

\section{METODOLOGI}

\section{Metode Pengambilan Sampel}

Menurut Sugiyono (2015:80), populasi adalah wilayah generalisasi yang terdiri atas objek atau subjek yang mempunyai kualitas dan karakteristik tertentu yang ditetapkan oleh peneliti untuk dipelajari dan kemudian ditarik kesimpulannya. Berdasarkan kualitas dan ciri tersebut, populasi dapat dipahami sebagai sekelompok individu atau objek pengamatan yang minimal memiliki satupersamaan karakteristik. Populasi dalam penelitian ini yaitu seluruh nasabah yang menerima pelayanan dari Bank Bengkulu Unit Panoramadengan rata-rata perhari sebanyak 75 sampai 100 orang nasabah.

Sampel adalah bagian dari jumlah dan karakteristik yang dimiliki oleh populasi tersebut (Sugiyono, 2015:81). 81). Sampel dari penelitian ini diambil 10 orang perhari selama 8 hari, sehingga jumlah sampel pada penelitan ini adalah 80 orang nasabah yang menerima pelayanan dari Bank Bengkulu Unit Panorama. Teknik pengambilan sampel adalah teknik accidental sampling yaitu memilih siapa saja anggota populasi yang secara kebetulan bertemu dianggap dapat memberikan imformasi yang diperlukan (Sugiyono, 2015: 85)

\section{Metode Pengumpulan Data}

Metode pengumpulan data dimaksudkan untuk memperoleh informasi yang relevan, akurat dan reliabel. Metode yang di gunakan adalah kuesioner. Kuesioner merupakan teknik 
pengumpulan data yang dilakukan dengan cara memberi seperangkat pertanyaan atau pernyataan tertulis kepada responden untuk dijawabnya (Sugiyono, 2015:142). Data yang diperoleh dalam penelitian ini didapatkan langsung dari pengisian kuesioner (angket) yang ditujukan kepada responden.

Pertanyaan-pertanyaan pada angket tertutup dibuat dengan skala likert dengan skor 1-5. Skala ini digunakan peneliti karena lebih sederhana dan memiliki nilai tengah yang digunakan untuk menjelaskan keragu-raguan atau netral dalam memilih jawaban.

Tabel 1. Skala Likert

\begin{tabular}{|l|c|}
\hline \multicolumn{1}{|c|}{ Pilihan Jawaban } & Skor \\
\hline Sangat Tidak Setuju & 1 \\
\hline Tidak Setuju & 2 \\
\hline Netral & 3 \\
\hline Setuju & 4 \\
\hline Sangat Setuju & 5 \\
\hline
\end{tabular}

Sumber : Sugiyono, 2015:93

\section{Metode Analisis}

Metode analisis yang digunakan dalam penelitian ini adalah menggunakan Korelasi Rank Spearman dan uji hepotesis sebagai berikut :

a. Korelasi Rank Spearman

Menurut Sugiyono (2013:245) dalam korelasi rank spearman sumber data untuk kedua variabel yang akan dikonversikan dapat berasal dari sumber yang tidak sama, jenis data yang dikorelasikan adalah data ordinal, serta data dari kedua variabel tidak harus membentuk distribusi normal. Jadi korelasi rank spearman adalah bekerja dengan data ordinal atau berjenjang atau rangking, dan bebas distribusi. Adapun rumus korelasi rank spearman adalah :

$$
\rho=1-\frac{6 \sum b i^{2}}{n\left(n^{2}-1\right)}
$$

( Sugiyono, 2013:245)

Keterangan :

$$
\begin{array}{ll}
\rho & =\text { Koefisien korelasi rank spearman } \\
\mathrm{n} & =\text { Jumlah sampel } \\
\sum b i^{2} & =\text { Jumlah kuadrat dari selisih variabel }
\end{array}
$$

Untuk dapat memberikan penafsiran terhadap koefesien korelasi yang ditemukan tersebut besar atau kecil, maka dapat berpedoman pada ketentuan sebagai berikut :

Tabel 2. Interprestasi Koefisien Korelasi

\begin{tabular}{|l|l|}
\hline Interval Koefesien & Tingkat Hubungan \\
\hline $0,00-0,199$ & Sangat rendah \\
\hline $0,20-0,399$ & Rendah \\
\hline $0,40-0,599$ & Sedang \\
\hline $0,60-0,799$ & Kuat \\
\hline $0,80-1,000$ & Sangat kuat \\
\hline
\end{tabular}

Sumber : Sugiyono, 2013:184

b. Uji Hipotesis $\mathrm{t}$

Uji Hipotesis untuk mengetahui tingkat signifikansi dari korelasi, maka penulis menggunakan statistik uji t dengan rumus sebagai berikut : 


$$
\begin{aligned}
& t_{\text {hitung }}=r \sqrt{\frac{n-2}{1-r^{2}}} \\
& \text { ( Sugiyono, } 2013: 184 \text { ) } \\
& \text { Keterangan : } \\
& \mathrm{t}=\text { nilai uji } \mathrm{t} \\
& \mathrm{p}=\text { nilai koefisien korelasi } \\
& \mathrm{n}=\text { jumlah sampel }
\end{aligned}
$$

Agar hasil perhitungan koefisien korelasi dapat diketahui signifikan atau tidak signifikan maka hasil perhitungan dari statistik uji $\mathrm{t}\left(\mathrm{t}_{\text {hitung }}\right)$ tersebut selanjutnya dibandingkan dengan $\mathrm{t}_{\text {tabel. }}$. Tingkat signifikannya yaitu $5 \%(\alpha=0,05)$ dengan uji satu pihak dan derajat kebebasannya $(\mathrm{dk}=$ n-3), artinya jika hipotesis nol ditolak dengan taraf kepercayaan $95 \%$, maka kemungkinan bahwa hasil dari penarikan kesimpulan mempunyai kebenaran $95 \%$ dan hal ini menunjukan adanya hubungan (korelasi) yang meyakinkan (signifikan) antara dua variabel tersebut.

Hipotesis yang digunakan dalam pengujian ini adalah :

$\mathrm{H}_{0}$ : service recovery tidak mempunyai hubungan signifikan dengan loyalitas nasabah pada Pada Bank Bengkulu Unit Panorama

$\mathrm{H}_{\mathrm{a}}$ : $\quad$ service recovery mempunyai hubungan signifikan dengan loyalitas nasabah pada Pada Bank Bengkulu Unit Panorama

Dengan kriteria pengujian sebagai berikut :

a. Apabila $\mathrm{t}_{\text {hitung }}<\mathrm{t}_{\text {tabel}}$, maka $\mathrm{H}_{0}$ diterima dan $\mathrm{H}_{\mathrm{a}}$ ditolak.

b. Apabila $t_{\text {hitung }}>t_{\text {tabel }}$, maka $\mathrm{H}_{0}$ ditolak dan $\mathrm{H}_{\mathrm{a}}$ diterima.

\section{HASIL DAN PEMBAHASAN}

\section{Hasil}

Untuk mengetahui hubungan service recovery dengan loyalitas nasabah pada Bank Bengkulu Unit Panorama dianalisa dengan korelasi rank spearman dengan rumus :

$$
\rho=1-\frac{6 \sum b i^{2}}{n\left(n^{2}-1\right)}
$$

Berdasarkan lampiran 6 tentang tabel penolong korelasi rank spearman untuk hubungan service recovery dengan loyalitas nasabah pada Bank Bengkulu Unit Panorama diketahui:

$\mathrm{bi}^{2}=22.444$

$\mathrm{n} \quad=80$

Maka korelasi rank spearman untuk hubungan service recovery dengan loyalitas nasabah pada Bank Bengkulu Unit Panorama dapat diihitung sebagai berikut :

$$
\begin{aligned}
\rho & =1-\frac{6 \sum b i^{2}}{n\left(n^{2}-1\right)} \\
\rho & =1-\frac{6(22.444)}{80\left(80^{2}-1\right)} \\
& =1-\frac{134.664}{80(6.400-1)} \\
\rho & =1-\frac{134.664}{80(6.399)} \\
\rho & =1-\frac{134.664}{511.920} \\
\rho & =1-0,263 \\
\rho & =0,737
\end{aligned}
$$


Diketahui bahwa besar korelasi service recovery dengan loyalitas nasabah pada Bank Bengkulu Unit Panorama, adalah sebesar 0,737.

Keterangan :

0,00-0,199 $=$ Sangat rendah

$0,20-0,399=$ Rendah

$0,40-0,599=$ Sedang

$0,60-0,799=$ Kuat

$0,80-1,000=$ Sangat Kuat

( Sugiyono, 2013:184)

Artinya antara service recovery dengan loyalitas nasabah pada Bank Bengkulu Unit Panorama memiliki hubungan yang "kuat" karena 0,737 terletak diantara 0,60-0,799. Hal ini menunjukkan bahwa terdapat korelasi yang kuat antara service recovery dengan loyalitas nasabah pada Bank Bengkulu Unit Panorama. Artinya semakin bagus service recovery yang diberikan maka akan semakin meningkatkan loyalitas nasabah pada Bank Bengkulu Unit Panorama

\section{Pengujian Hipotesis}

Untuk menguji tingkat signifikansi korelasi rank spearman, maka dilakukan uji hipotesis statistik. Rumus yang digunakan untuk menguji hipotesis statistik dalam penelitian tentang hubungan service recovery loyalitas nasabah pada Bank Bengkulu Unit Panorama adalah uji t makadapat diketahui :

$\rho=0,737$

$\mathrm{n}=80$

Rumus untuk uji $\mathrm{t}_{\text {hitung }}$ adalah sebagai berikut

$$
\begin{aligned}
t & =t \sqrt{\frac{n-2}{1-r^{2}}} \\
t & =0,737 \sqrt{\frac{80-2}{1-0,737^{2}}} \\
t & =0,737 \sqrt{\frac{78}{1-0,543}} \\
t & =0,737 \sqrt{\frac{78}{0,457}} \\
t & =0,737 \sqrt{170,678} \\
t & =0,737(13,064) \\
t & =9,628
\end{aligned}
$$

Dari hasil uji hipotesis diperoleh nilai $t_{\text {hitung }}$ adalah 9,628 kemudian dibandingkan dengan dengan nilai $\mathrm{t}_{\text {tabel }}$ dengan level of signifikan ditetapkan 95\% dengan perhitungan satu arah dan $\mathrm{dk}=$ $\mathrm{n}-2=80-2=78$, maka diketahui nilai $\mathrm{t}_{\text {tabel }}$ sebesar 1,664 seperti tabel terlampir. Sehingga didapat data sebagai berikut : 
Tabel 4. Uji Hipotesis Service recovery (X) dengan Loyalitas nasabah (Y)

\begin{tabular}{|c|c|c|}
\hline Keterangan & Nilai & Artinya \\
\hline $\mathrm{t}_{\text {hitung }}$ & 9,628 & $\begin{array}{l}\mathrm{t}_{\text {hitung }}>\mathrm{t}_{\text {tabel }} \text { maka } \mathrm{H}_{0} \text { ditolak } \mathrm{H}_{\mathrm{a}} \text { diterima, } \\
\text { artinya service recovery mempunyai hubungan }\end{array}$ \\
\hline$t_{\text {tabel }}$ & 1,664 & nasabah pada Bank Bengkulu Unit Panorama \\
\hline
\end{tabular}

Berdasarkan tabel 4 diatas, maka diketahui nilai $t_{\text {hitung }}$ lebih besar dari nilai $t_{\text {tabel }}$ $(9,628>1,664)$ artinnya service recovery memiliki hubungan yang positif dan signifikan dengan loyalitas nasabah pada Bank Bengkulu Unit Panorama. Hal ini menerangkan bahwa terdapat hubungan yang erat antara service recovery dengan loyalitas nasabah, apabila service recovery yang diberikan baik maka nasabah akan merasa puas dan senang menabung di Bank Bengkulu Unit Panorama.

\section{Pembahasan}

Berdasarkan pengujian analisis korelasi rank spearman dan uji hipotesis uji t maka dapat dijelaskan hasil dari pengujian tersebut seperti pada tabel dibawah ini :

Tabel 5. Hasil Pengujian Korelasi Rank Spearman dengan Hipotesis

\begin{tabular}{|c|c|c|c|c|c|}
\hline Variabel & $\boldsymbol{\rho}$ & Artinya & $\mathbf{t}_{\text {hitung }}$ & $\mathbf{t}_{\text {tabel.(n-2) }}$ & Ket \\
\hline $\begin{array}{c}\text { Service } \\
\text { recovery } \\
\text { dengan }\end{array}$ & 0,737 & Kuat & 9,628 & 1,664 & $t_{\text {hitung }}>t_{\text {tabel }}$ \\
Kepuasan & & & & & \\
\hline
\end{tabular}

Berdasarkan hasil pengujian secara statistik dapat terlihat dengan jelas bahwa variabel bebas berpengaruh terhadap variabel terikat. Pengaruh yang diberikan variabel bebas tersebut bersifat positif artinya semakin bagus service recovery yang diberikan oleh Bank Bengkulu Unit Panorama maka akan semakin tinggi pula tingkat loyalitas nasabah pada Bank Bengkulu Unit Panorama.

Hasil penelitian menunjukkan bahwa service recovery pada Bank Bengkulu Unit Panorama sudah baik. Dari segi service recovery yang diberikan para nasabah sudah merasa puas dengan service recovery yang sopan santun dan ramah tamah, serta service recovery yang cepat dan selalu memberikan informasi kepada para nasabah. Semua ini harus bisa dipertahankan oleh Bank Bengkulu Unit Panorama agar citranya yang sudah baik dimata nasabah bisa terus dipertahankan.

Hal ini menggambarkan dengan service recovery Bank Bengkulu Unit Panorama mampu menciptakan loyalitas dari pelanggan, meskipun Bank Bengkulu Unit Panorama pernah melakukan kesalahan dalam pelayanan terhadap pelanggan tetapi Bank Bengkulu Unit Panorama mampu memperbaiki pelayanan tersebut dengan cara meminta maaf kepada pelanggan, memperbaiki pelayanan, melakukan komunikasi yang lancar dengan pelanggan dan menjawab semua keluhan dari pelanggan. Service recovery yang dilakukan oleh Bank Bengkulu Unit Panorama ini mampu mengatasi kegagalan jasa yang dirasakan oleh konsumen sehingga konsumen tetap menjadi pelanggan yang setia.

Hasil penelitian ini sejalan dengan pendapat yang disampaikan oleh Lovelock (2016:177) menjelaskan bahwa pemulihan layanan jasa yang efektif membutuhkan prosedur yang cermat untuk memecahkan masalah dan menangani pelanggan yang tidak puas. Sangat penting perusahaan memiliki strategi-strategi pemulihan yang efektif karena bahkan satu masalah jasa pun dapat menghancurkan kepercayaan pelanggan kepada perusahaan.

Perusahaan bahkan harus menciptakan formula untuk menghubungkan nilai dari mempertahankan pelanggan yang menguntungkan terhadap keseluruhan biaya yang dibutuhkan 
untuk menjalankan unit penangan keluhan. Berdasarkan hal tersebut, terdapat fakta sederhana bahwa ketika pelanggan yang tidak puas pergi, maka perusahaan akan kehilangan lebih dari nilai transaksi berikutnya. Perusahaan bahkan dapat kehilangan keuntungan dalan jangka panjang dari pelanggan tersebut dan siapa saja yang beralih dari penyedia jasa tersebut karena komentar negatif dari pelanggan yang tidak puas. Untuk itu dibutuhkan investasi dalam desain service recovery untuk melindungi keuntungan jangka panjang (Lovelock dan Wright, 2016:108).

Beberapa keluhan dibuat ketika penyampaian jasa sedang dilakukan dan beberapa yang lain ketika penyampaian jasa telah dilakukan. Dalam kedua kasus tersebut, keluhan yang ditangani mungkin saja menentukkan apakah pelanggan akan tetap menggunakan jasa perusahaan atau berpindah ke penyedia jasa lain. Keuntungan dari mendapatkan keluhan langsung adalah kemungkinan adanya kesempatan untuk mengkoreksi situasi sebelum penyampaian jasa selesai dilakukan. Namun, kekurangannya adalah mungkin saja pegawai yang menangani langsung menjadi demotivasi. Kesulitan sebenarnya bagi karyawan adalah terkadang memiliki kekurangan wewenang dan alat untuk memecahkan permasalahan konsumen. Ketika keluhan disampaikan sesudah penyampaian jasa terjadi, maka pilihan-pilihan untuk melakukan pemulihan semakin terbatas. Dalam kasus ini, perusahaan dapat melakukan permohonan maaf, mengulangi jasa atau memberikan solusi permasalahan maupun menawarkan berbagai bentuk kompensasi (Lovelock, 2016:98.

\section{KESIMPULAN}

Dari pembahasan yang telah diuraikan, maka dapat ditarik kesimpulan sebagai berikut.

1. Hasil korelasi rank spearman menunjukkan hubungan yang kuat antara service recovery dengan loyalitas nasabah Bank Bengkulu Unit Panorama dengan nilai korelasi sebesar 0,737. Hal ini menunjukkan bahwa terdapat korelasi yang kuat antara service recovery dengan loyalitas nasabah. Semakin baik service recovery maka akan semakin meningkat tingkat loyalitas nasabah pada Bank Bengkulu Unit Panorama.

2. Hasil pengujian hipotesis nilai $t_{\text {hitung }}$ lebih besar dari nilai $t_{\text {tabel }}(9,628>1,664)$ artinya service recovery memiliki hubungan yang signifikan dengan loyalitas nasabah pada Bank Bengkulu Unit Panorama. Hal ini menerangkan bahwa terdapat hubungan yang erat antara service recovery dengan loyalitas nasabah.

\section{Saran}

Berdasarkan kesimpulan yang telah dilakukan maka saran yang dapat diberikan dalam penelitian ini yaitu disarankan kepada Bank Bengkulu unit Panorama untuk berusaha mencari akar permasalahan dari setiap kegagalan dan kesalahan dari sebuah pelayanan, sehingga dengan demikian maka perusahaan dapat merumuskan solusi terbaik terhadap setiap masalah / keluhan yang timbul. Salah satu keuntungan belajar dari kesalahan layanan dari masa lalu adalah perusahaan dapat mengantisipasi kegagalan pelayanan di masa yang akan datang.

\section{DAFTAR PUSTAKA}

Boshoff, Christo. (2015). A re-assessment and refinement of RECOVSAT", Managing Service Quality: An International Journal, Vol. 15 Iss 5

Ghozali, Imam. (2015). Aplikasi Analisis Multivariate Dengan Program SPSS. Semarang: Badan Penerbit Universitas Diponegoro

Griffin. Jill. (2015). Customer Loyalty : Menumbuhkan dan Mempertahankan Kesetiaan Pelanggan. Alih bahasa : Dwi Kartini Yahya dan kawan kawan. Jakarta: Erlangga

Handoko, T. Hani. (2015), Manajemen Sumber Daya Manusia, Bumi Aksara, Jakarta. Hurriyati, Ratih. (2015). Bauran Pemasaran dan Loyalitas Konsumen. Alfabeta. Bandung Kasmir, (2016). Bank dan Lembaga Keuangan Lainnya. Jakarta : PT. Raja Grafindo Persada

Kau, A. K. and E. W. Loh. (2016). The Effects of Service Recovery on Customer Satisfaction; A Comparison Between Complaints and Non-Complainants. Journal of Services Marketing 
Kaunang, Dewi Tresya. (2015). Analisis Pengaruh Kualitas Produk dan Kualitas Layanan terhadap Loyalitas Nasabah yang dimediasi oleh Kepuasan Nasabah (Studi pada Nasabah Taplus PT Bank Negara Indonesia (Persero) Tbk Kantor Cabang Manado). Jurnal Riset Bisnis dan Manajemen Vol.3,No.2, 2015:187-198

Kotler dan Amstrong. (2014). Prinsip-prinsip Marketing. Edisi Ketujuh. Penerbit Salemba Empat. Jakarta.

Kotler, Philip. (2014). Manajemen Pemasaran. : Erlangga: Jakarta

Lovelock, Cristhoper H dan Lauren K. Wright. 2016. Manajemen Pemasaran Jasa. Alih bahasa Agus Widyantoro. Cetakan Kedua. Indeks: Jakarta

Lupiyoadi, Rambat. (2016). Manajemen Pemasaran Jasa Berbasis Kompetensi. Jakarta: Salemba Empat

Martono. (2014). Manajemen Keuangan. Edisi Kedua, Cetakan Pertama, Penerbit EKONISIA, Yogyakarta.

Nursyamsiah, Siti. (2012). Pengaruh Service Recovery Terhadap Loyalitas. 36 Efektif Jurnal Bisnis dan Ekonomi EfEktif Jurnal Bisnis dan Ekonomi Vol. 2, No. 2, Desember 2011, 136 $-147$

Parasuraman, A.(2017). Reflections on Gaining Competitive Advantage through Customer Value. Journal ofthe Academy of Marketing Science 25(2): 154-161

Setiawan, Budi. (2015). Menganalisa Statistik Bisnis dan Ekonomi dengan SPSS 21. Jakarta: Andi

Shapiro Terri and Jennifer Nieman-Gonder. (2016). Effect of communication mode in justicebased service recovery. Managing Service Quality Vol. 16 No. 2, 2006 pp. 124-144

Smith, A., Bolton, R. and Wagner, J. (2014). A Model of Customer Satisfaction with Service Encounters Involving Failure and Recovery. Journal of Marketing Research. Vol. 34, August, pp. 356-372.

Sugiyono. (2015). Metode penelitian pendidikan: pendekatan kuantitatif. kualitatif. dan $R \& D$. Alfabeta : Bandung.

Sunyoto, Danang. (2012). Konsep Dasar Riset Pemasaran Dan Prilaku Konsumen. Cetakan Ke empat. Andi. Yogyakarta.

Sutisna. (2014). Perilaku Konsumen \& Komunikasi Pemasaran. Rosdakarya: Bandung

Swastha, Basu. (2016). Manajemen Pemasaran.: Universitas Terbuka: Tanggerang Selatan

Tjiptono, Fandy. 2017. Manajemen Pelayanan Jasa. Penerbit Andi. Yogyakarta.

Zemke, R., dan Bell, C., (2013). Service Recovery: Doing it Right the Second Time, Journal Training, Vol.27, No.6, pp. 42-4. 